ПРОФЕСІЙНО-МОВЛЕННЄВА КОМПЕТЕНТНІСТЬ

ЯК ОДНА З ГОЛОВНИХ ВИМОГ ФОРМУВАННЯ ОСОБИСТОСТІ СУЧАСНОГО ВЧИТЕЛЯ ФІЗИЧНОЇ КУЛЬТУРИ

\title{
PROFESSIONAL SPEECH COMPETENCE AS ONE OF THE MAIN REQUIREMENTS OF FORMATION OF A MODERN PHYSICAL CULTURAL TEACHER'S PERSONALITY
}

Стаття присвячена проблемі орормування профресійно-мовленнєвої культури майбутніх вчителів фрізичної культури. Обірунтовані теоретико-методичні засади ґенези мовлення та культури вчителя фрізичної культури. Визначені соціально-фрілосоорські, психолого-педагогічні та оздоровчо-педагогічні передумови для розвитку системи формування просресійно-мовленнєвої культури майбутніх фрахівців фрізичного виховання. Виокремлені структурні компоненти системи формування просресійно-мовленнєвої культури майбутніх фрахівців фрізичного виховання. У процесі аналізу існуючих концепцій виокремлені такі основні аспекти, які впливають на фрункціонування наукової організаційно-методичної системи формування мовленнєвих умінь: соціокультурний, психологічний та педагогічний. Визначена специ фріка профресійно-мовної культури майбутніх учителів фрізичної культури. Досліджені особливості просресійної діяльності вчителя фрізичної культури та специфріка фрізкультурно-спортивної діяльності. Пропонується розглядати прочес формування професійномовленнєвої культури майбутніх фрахівців 3 фозичної культури і спорту як сукупність дій, спрямованих на соормування мовленнєвих умінь і навичок, засвоєння норм літературної мови і розвиток навички самоконтролю за їх дотриманням, збагачення словникового запасу і формування навички публічних виступів. Автор робить висновок, що смислове сприйняття мови не завжди визначається тільки характером повідомлення. Багато в чому воно залежить від мовної компетент ності реципієнта, його мовного досвіду, словникового запасу, підготовленості до інтерпретації мовного повідомлення. Виявлено, що суть розуміння проблеми мовленнєвої підготовки майбутнього вчителя фрізичної культури в контексті формування його майстерності визначається домінуванням самого мовлення як виду професійної діяльності на всіх етапах роботи й у різних сфрерах його життєдіяльності. Пропонується ввести в навчальні плани для професійної підготовки вчителів напряму підготовки «Фізичне виховання» такі дисципліни, пов'язані з удосконаленням мовної культури майбутнього вчителя, як «Підвищення професійної майстерності», «Профресійно-мовна культура», «Акмеологія фрізичної культури і спорту». Ключові слова: мовлення, вччтель фрізичної культури, профресійно-мовленнєва компетентність.
The article is devoted to the problem of formation of vocational culture of future teachers of physical culture. The theoretical and methodological foundations of the genesis of speech and culture of the physical education teacher are substantiated. The social-philosophical, psychological-pedagogical and health-pedagogical preconditions for the development of the system of formation of professionalspeech culture of future specialists of physical education are determined. The structural components of the system of formation of professional-speech culture of future specialists of physical education are distinguished. In the process of analyzing existing concepts, the main aspects that influence the functioning of the scientific organizational and methodological system of speech skills formation are identified: socio-cultural, psychological and pedagogical. The specifics of professionallanguage culture of future physical education teachers have been determined. The specificity of physical-sports activity and peculiarities of professional activity of the teacher of physical culture are investigated. It is suggested to consider the process of formation of professional-speaking culture of future specialists in physical culture and sports as a set of the following actions of formation of speaking skills and skills, assimilation of norms of literary language and development of the selfcontrol skills for their observance, enrichment of vocabulary and formation of vocabulary. The author concludes that the semantic perception of language is not always determined solely by the nature of the message. In many respects it depends on the language competence of the recipient, his or her language experience, vocabulary, readiness to interpret the language message. It is determined that the essence of understanding the problem of speech training of a future physical education teacher in the context of forming his mastery is determined by the dominance of speech itself as a type of professional activity at all stages of work and in various spheres of his life. It is proposed to introduce into the curricula for vocational training of teachers of the field of preparation of "Physical education" such disciplines related to the improvement of linguistic culture of the future teacher, such as "Improvement of professional skills", "Vocational-linguistic culture", "Acmeology of physical culture and sports". Key words: speech, physical education teacher, vocational competence. університету

Постановка проблеми у загальному вигляді. Одним із завдань вищої школи України є забезпечення набуття студентами знань 3 певної галузі наук та підготовка їх до професійної діяльності. Виникла потреба у фрахівцях нової формації в галузі фрізичної культури і спорту, спроможних пра- цювати за сучасних умов розвитку державності в Україні, здатних до створення оптимальних умов саморозвитку, самоосвіти і самореалізації особистості упродовж їі навчання у різних типах закладів освіти. Шляхи розв'язання таких завдань зумовлені підвищенням ролі особистості вчителя фрізич- 
ної культури як фрахівця і громадянина для поліпшення соціального, господарського, культурного життя суспільства в умовах сьогодення. Соціальне замовлення актуалізує сутнісний зміст педагогічної освіти, її діяльний характер, скерований не лише на активну життєву позицію, поважне ставлення до себе, інших, але й на формування фрахівця, здатного передавати учням комплекс окреслених програмою знань та вмінь, дбати про коморортне почуття, своє здоров'я і здоров'я своїх вихованців.

Аналізуючи сучасну теорію і практику мовленнєвої підготовки майбутніх учителів, можна стверджувати, що ще недостатньо вивчено та розроблено теоретичні засади формування у студентів мовленнєвої компетентності. Існує нагальна потреба опрацювання і поширення результатів відповідних досліджень і досвіду з цього напрямку в університетській освіті, об'єктивної оцінки пропонованих технологій навчання і вивчення можливих шляхів удосконалення якості професійної мовленнєвої підготовки випускників вищої школи.

Закономірно, що в цій ситуації необхідним $€$ пошук нових рішень у галузі професійної мовленнєвої культури майбутнього вчителя, вдосконалення механізмів, які регулюють якість його мовленнєвої діяльності.

До причин, що визначають актуальність зазначеної проблеми, слід віднести й соціальну ситуацію, зокрема й у коледжах фрізкультурної спрямованості, де мовлення стає одним із мобільних чинників, спроможних впливати на студента. А це спонукає до створення і реалізації науково обґрунтованої педагогічної системи, яка дає можливість забезпечити переведення наявної загальнопедагогічної системи у якісно новий стан, оптимізувати зміст організації й управління процесом фрормування професійного мовлення.

Безперечним $€$ твердження, що мовленнєва культура - це компонент загальної культури людини, її інтелектуального розвитку. Знання рідної мови, норм її застосування - сьогодні це не тільки ознака культурного розвитку людини, а й умова іï̈ успішної кар'єрної діяльності. Тому, на нашу думку, одним із пріоритетних напрямів вивчення фрілологічних дисциплін варто вважати орієнтацію на фрормування мовленнєвої компетенції у сорері ділового і професійного спілкування. Проблема мовленнєвої культури багатоаспектна, складна і пов'язана з комплексом питань власне лінгвістичного, культурологічного, соціального характеру, а також з моделлю освіти, запит на яку фрормує певна політична система. Сучасне суспільство фрормує запит на спеціаліста як особистість, що здатна реалізовувати високі професійні якості, засвоювати нові знання, мати активну ділову співпрацю і комунікації.

Напрямами профресійної діяльності фрахівця з фрізичної культури $є$ фрізичне виховання, спорт та здоров'я людини. У процесі розвитку діяльності фрахівців з фрізичної культури фрормуються професійні норми, правила, вимоги до представників означеної ссрери діяльності. Такі вимоги передбачають необхідний обсяг знань, умінь і навичок, особистісні якості, ставлення до професійної діяльності.

Актуальність статті зумовлена завданням сорормувати в майбутніх вчителів фрізичної культури правильне фрахове мовлення. Теоретичною основою дослідження стала методична та лінгводидактична література, де приділяється увага проблемам формування мовленнєвої культури (О. Біляєв, А. Коваль, О. Олійник, Г. Волкотруб, В. Пасинок, М. Пентилюк та інші), ідеям комунікативно-діяльнісного підходу до навчання мови (С. Шевчук, І. Ґудзик, Л. Мацько та інші).

Підсумовуючи зазначене, зауважимо, що фрормування професійно-мовленнєвої компетенції складова частина професійної підготовки майбутнього вчителя фрізичної культури, діяльність якого неможлива без міцних і глибоких знань у галузі культури української мови. Все сказане визначає актуальність проблеми з впровадження в практику навчальних закладів різного типу ефективних технологійфрормуванняпрофресійно-мовленнєвоїкультури майбутніх фрахівців фрізичної культури і спорту.

Аналіз останніх досліджень і публікацій. Педагоги ті психологи вивчають взаємодії різних чинників, що сприяють успішному розвитку професійного мовлення у студента. Визначальними є погляди вчених Л. Виготського, І. Зимньої, І. Зязюна, А. Капської, О. Леонтьєва, Л. Нечепоренко, Г. Сагач, В. Семиченко та інших, які вказують на об'єктивну потребу й можливість фрормування цього важливого компонента педагогічної майстерності.

Мовленнєві вміння вчителя вивчалися як об'єктивна ознака його готовності до професійної діяльності. Це переконливо доведено в дослідженнях Ш. Амонашвілі, Н. Бабич, Н. Головань, Л. Зінченко, О. Горської, Н. Жигилій, О. Іванової, К. Левітана, в яких підкреслюється специфіка мовленнєвих умінь як прояв професіоналізму.

Міжнародний науковий досвід має позитивні напрацювання у напрямі фрормування профресійно-мовленнєвої культури спілкування майбутнього вчителя фрізичної культури. Достатньо ґрунтовно розкрито процес формування теорії комунікації, закономірності та принципи моделювання процесу обміну інорормацією, особливості організації й управління процесом комунікації в наукових працях таких зарубіжних вчених, як Л. Баркер, Н. Лаура, С. Рамсі, Д. Хаймс. Визначаючи наявні підходи до професійної підготовки майбутніх учителів, Н.П. Волкова виділяє окремий напрям їх підготовки до професійної комунікативної діяльності як компонент педагогічної мовлен- 
нєвої культури, до якого належать такі складники: особистісно-діяльнісний підхід, складниками якого $€$ зміна фрорми комунікації у навчально-виховному процесі, персоналізація педагогічної взаємодії, перетворення суперпозиції викладача і субординізованої позиції студента в індивідуально-рівноправні позиції, реалізація у навчальному процесі механізму взаємообміну між викладачами й студентами педагогічно-рольовими фрункціями. За системного підходу, який орієнтує на розкриття цілісності педагогічних об'єктів, виявлення в них різноманітних типів зв'язку, доведено, що процес підготовки майбутніх учителів має розглядатися як цілісна система, упорядкована множина взаємопов'язаних компонентів, що $€$ цілісним утворенням. Визначено, що за ціннісно-діяльнісного підходу зміст підготовки майбутніх учителів має бути представлений ціннісно-змістовними, емоційно насиченими, професійно спрямованими елементами, включеними у контекст життєвих, професійно-комунікативних проблем студента завдяки моделюванню особистісно орієнтованих комунікативних ситуацій. Дослідницею обґрунтовано доцільність синергетичної методології у вирішенні проблеми підготовки майбутніх учителів [2, c. 56].

Виділення не вирішених раніше частин загальної проблеми. Слід зазначити, що останнім часом значно активізувалися психолого-педагогічні дослідження українськими вченими різних аспектів фрормування професійної мовленнєвої компетентності майбутніх учителів фрізичної культури. Цікавими для науковців є такі аспекти: культура відносин, що впливає на самоактуалізацію і самореалізацію потенціалу професійної компетентності вчителя фрізичної культури (Т. Калюжна, І. Омельяненко та інші), професійно-педагогічне мовлення як частина професійної компетентності (Л. Безкоровайна, А. Сущенко та інші), комунікативна компетентність учителя (К. Касярум), професійно-мовленннєва культура майбутніх фрахівців фрізичного виховання (Г.Д. Кондрацька).

Більшість авторів зазначає відсутність сорормованої системи у становленні професійно-мовленнєвої культури, спонукає до необхідності активного пошуку ефективних технологій, наукових досліджень окресленої проблеми. Їхні позиції об'єднані спільним розумінням неспроможності сучасної системи навчання мови, розвитку мовної культури.

Отже, аналіз міжнародних та вітчизняних науково-педагогічних джерел засвідчує актуальність проблеми фрормування професійно-мовленнєвої культури в майбутніх фрахівців фрізичної культури і спорту. Водночас сьогодні недостатньо вивчений взаємозв'язок між професійним мовленням і фрізичним вихованням, недостатньо узагальнені технології, фрорми та методи фрормування комунікативної компетентності та культури відносин у процесі профресійної підготовки в коледжах фрізкультурної спрямованості.

Мета статті. 3 огляду на актуальність проблеми мовленнєвої компетентності сучасного вчителя фрізичної культури метою статті є обґрунтування теоретичних основ фрормування мовленнєвої компетентності студентів коледжів напряму підготовки «Фізичне виховання».

Виклад основного матеріалу. Питання вивчення функцій мови у сучасному суспільстві розглядається по-новому. Знання мови - це знання свого фраху, рівень опанування професійною мовою, фраховою термінологією.

Водночас із підвищенням рівня знань представників різних профресій підвищуються і вимоги до мовлення. Для вчителя фрізичної культури це означає вільно використовувати необхідні слова, вирази і команди у конкретній ситуації, влучно добирати і вільно володіти лексикою свого фраху, не допускати стильового і стилістичного дисонансу, вільно виражати свою думку тощо. Саме тому знання мови - це один із компонентів професійної підготовки, адже мова виражає думку, є засобом пізнання і діяльності, тому правильному професійному спілкуванню людина вчиться протягом життя. Знання мови професії підвищує ефективність праці, допомагає краще орієнтуватись у складній профресійній ситуації та у контактах з представниками своєї профресії [1, с. 159].

Організація мовленнєвої діяльності в умовах вищої фрізкультурної освіти передбачає засвоєння майбутніми вчителями фрізичної культури знань про мову і мислення, набуття ними власного мовленнєвого досвіду, спрямованість особистості до саморозвитку і самореалізації, фрормування самосвідомості як передумови самостійності в оволодінні професійними мовленнєвими уміннями, що супроводжуються відповідним корегуванням, підвищенням рівня профресійної зрілості під час оволодіння різними мовленнєвими фрункціями.

Загальний мовленнєвий розвиток студента визначається якісним рівнем його мовленнєвої культури, що виявляється як у професійній діяльності, так і в процесі його самореалізації у навчанні, досягненні поставленої мети, осмисленні сутності профресійної діяльності.

На нашу думку, підходи науковців до проблеми фрормування професіоналізму майбутнього вчителя фрізичної культури з чіткою орієнтацією на мовленнєву компетентність не випадкові, адже робота вчителя передбачає безпосереднє спілкування з учнями, батьками та колегами. Для цього слід опиратися на такі категорії: зміст мовлення (новизна, актуальність, конкретність, цільова спрямованість), структура мовлення (тривалість звучання, використання термінів, дублетів, знання терміноелементів тощо), комунікативна вправність (інформативність, правильність, логічність, 
точність, чистота, доречність, виразність), звукове офрормлення (орфоепічні норми, морфологічний та синтаксичний аспекти), практична спрямованість (акцентування на потрібній інформації, переконливість, ясність викладу), імідж майбутнього вчителя фрізичної культури як представника еліти сучасного суспільства (професіоналізм, ставлення до учнів, колег, ерудованість, емоційність, стиль мовлення).

Отже, мовленнєва діяльність - це об'єктивний процес, оскільки він стосується носіїв мови, і водночас - це суб'єктивний процес, який реалізується завдяки мовленню суб'єкта.

Слід зазначити, що будь-яке фрахове мовлення, зокрема і фрізкультурно-педагогічне, - це частина загальнонаціональної мови. Фізична культура з усіма її формами і засобами вираження та застосування у суспільстві - це невід'ємна частина національної культури, а отже, вона вбирає в себе і мову, і численні традиції, зокрема й народної медицини, взаємодіє з іншими галузями науки.

Оскільки професія викладача фрізичної культури достатньо поширена, то фрункціонування і вивчення фрахового мовлення викладачів - одна з актуальних проблем мовознавства.

Використання української мови як державної у навчальній діяльності та профресійно-науковій роботі забезпечує пропаганду і розвиток української мови серед учнів, студентів, науковців, збагачуючи словниковий запас майбутніх професіоналів, додає престижу її використанню як в Україні, так і поза її межами.

Застосування української мови у професійному мовленні викладачів фрізичної культури забезпечує налагодження контакту з учнями, колегами і може відігравати роль психотерапевтичного чинника, а також пропагує мову, якою користуються педагоги. Під час вивчення та користування мовою важливим є виховний аспект, адже так відбувається пропаганда власне українського, виховання майбутнього патріота-срахівця, здатного розвивати і примножувати здобутки української мови як національної мови світу.

Аналізуючи сучасний підхід до фрормування майбутнього вчителя фрізичної культури, профе- сіонала своєї справи, інтелігента і патріота своєї держави, необхідно пам'ятати про консолідуюче значення мовленнєвого фрактора як одного з основних чинників фрормування особистості у контексті нових державотворчих, національно-культурних та морально-виховних перетворень.

Висновки. Отже, можна зробити висновок, що суть розуміння проблеми мовленнєвої підготовки майбутнього вчителя фрізичної культури в контексті формування його майстерності визначається домінуванням самого мовлення як виду професійної діяльності на всіх етапах роботи й у різних сорерах його життєдіяльності. Проблема фрормування правильності мовлення майбутніх учителів фрізичної культури не вичерпується матеріалами статті. Зазначене дозволяє поставити низку питань, вирішення яких сприятиме подальшому вдосконаленню різних видів мовленнєвої діяльності студентів під час вивчення профресійнонаправлених дисциплін, зокрема перспективними стануть дослідження особливостей фрормування професійного мовлення студентів нефілологічних спеціальностей мультимедійними засобами. Пропонуємо ввести в навчальні плани коледжів для профресійної підготовки учителів напряму підготовки «Фізичне виховання» такі дисципліни, пов'язані з удосконаленням мовленнєвої культури майбутнього учителя, як «Підвищення професійної майстерності», Профресійно-мовленнєва культура», «Акмеологія фрізичної культури і спорту».

\section{БІБЛІОГРАФІЧНИЙ СПИСОК:}

1. Кондрацька Г.Д. Методологічні основи фрормування профресійно-мовленнєвої культури майбутніх фахівців 3 фрізичного виховання у вищих навчальних закладах освіти. Науковий часопис Національного педагогічного університету імені М.П. Драгоманова : зб. наукових праць / за ред. О.В. Тимошенка. Київ : Вид-во НПУ імені М.П. Драгоманова, 2017. Випуск 5 К (86) 17. С. 159-162.

2. Волкова Н.П. Теоретичні та методичні засади підготовки майбутніх учителів до професійно-педагогічної комунікації : дис. ... докт. пед. наук: 13.00 .04 ; Луганський національний педагогічний університет імені Тараса Шевченка. Луганськ, 2006. 544 c. 